\title{
LOCAL CHALLENGES AND OPPORTUNITIES FOR LANGUAGE AND LITERACY RESEARCHERS AND EDUCATORS
}

\begin{abstract}
This paper presents a three dimensional array of contemporary challenges and opportunities for language and literacy researchers and educators. The challenges and opportunities result from dynamic human migration, widespread use of mobile digital technology, and the development of the internet. Recent publications are discussed that exemplify the challenges and opportunities. Particular attention is given to spaces as local contexts for language and literacy learning. Focusing discussion upon the challenges and opportunities is one way of building knowledge about how people use modes of communication to develop, use, and learn language and literacies.
\end{abstract}

KEYWORDS: language, literacy, research, education, local spaces.

1 david4landis@gmail.com

This paper was submitted on August 1st, 2017 and accepted for publication at the meeting of the Editorial Board held on September 19, 2017. 


\section{OVERVIEW}

Contemporary educators and researchers attentive to children and young people's language in use and literacy learning are encountering an array of opportunities and challenges. Such a formation can be constructed around three virtual, reference lines or axes ( $T$, $\mathrm{C}, \mathrm{K})$ located in a three-dimensional plane. The first axis (T) indicates three aspects of theorizing about language and literacy learning and instruction in: a) ordinary home and community living conditions, b) schools/classrooms, and c) education preparation and professional development opportunities (Hall, Cremin, Comber \& Moll, 2013). The second axis (C) indicates developing international collaborations for educators and researchers. The opportunities for international collaboration include: a) internships, b) comparative research projects, c) professional development and educational projects to improve teaching practices (Leung, Richards \& Lassonde, 2014). The third axis (K) indicates three particular challenges to building knowledge about language and literacy learning for contemporary students, teachers, and literacy researchers caused by changes in human migration, widespread use of mobile digital technology, and development of the internet (Blommaert \& Backus, 2011). The direction of the arrows shows that one common intersecting event, the writing of this paper, can be connected to these existing bodies of knowledge and their challenges of understanding (see Figure One). Taken together, these intersecting axes define a set of challenges and opportunities related to children and young people's language and literacy learning for contemporary literacy researchers and educators. The set of challenges and opportunities take a particular theoretical perspective that views language and literacy practices,

"[A]s situated in and constitutive of multiple and diverse human activities. The authors... favor a socio-cultural framing of language and literacy practices, with a predilection for studying these practices in the actual, living, or concrete conditions of life, whether located in homes, classrooms or digitally in some sort of in between context." (Hall et al., 2013, pp. xxxvii-xxxviii).

Taken together, the theoretical perspective of language and literacy practices as socio-cultural human activities plus the significant directions in literacy research and practice can be useful for 
1. Studying children's language and literacy learning in local conditions of ordinary life with focus on:

a) human activities mediated by language/communication with tools/artifacts in social relationships b) diversifying means for composing variety of textual meanings for possible use as cultural resources
2. Studying children's language and literacy learning in schools/classrooms with focus on:

a) hybrid modes of language use to make sense and meaning for engaging with reading/writing

b) space and place pedagogies

c) critical views of gender, race

d) teacher/student interactions and identities
3. Studying teachers (pre-service education and in-service professional development) with focus on:

a) building teacher knowledge and literate identities

b) addressing calls for reform of teacher education

c) meeting shifting demands upon curriculum and literacy practices d) focusing professional development to develop teacher knowledge

e) focusing professional development to identify learners' strengths, weaknesses

f) developing teacher researchteachers and students as researchers (Hall, Cremin, Comber \& Moll, 2013)

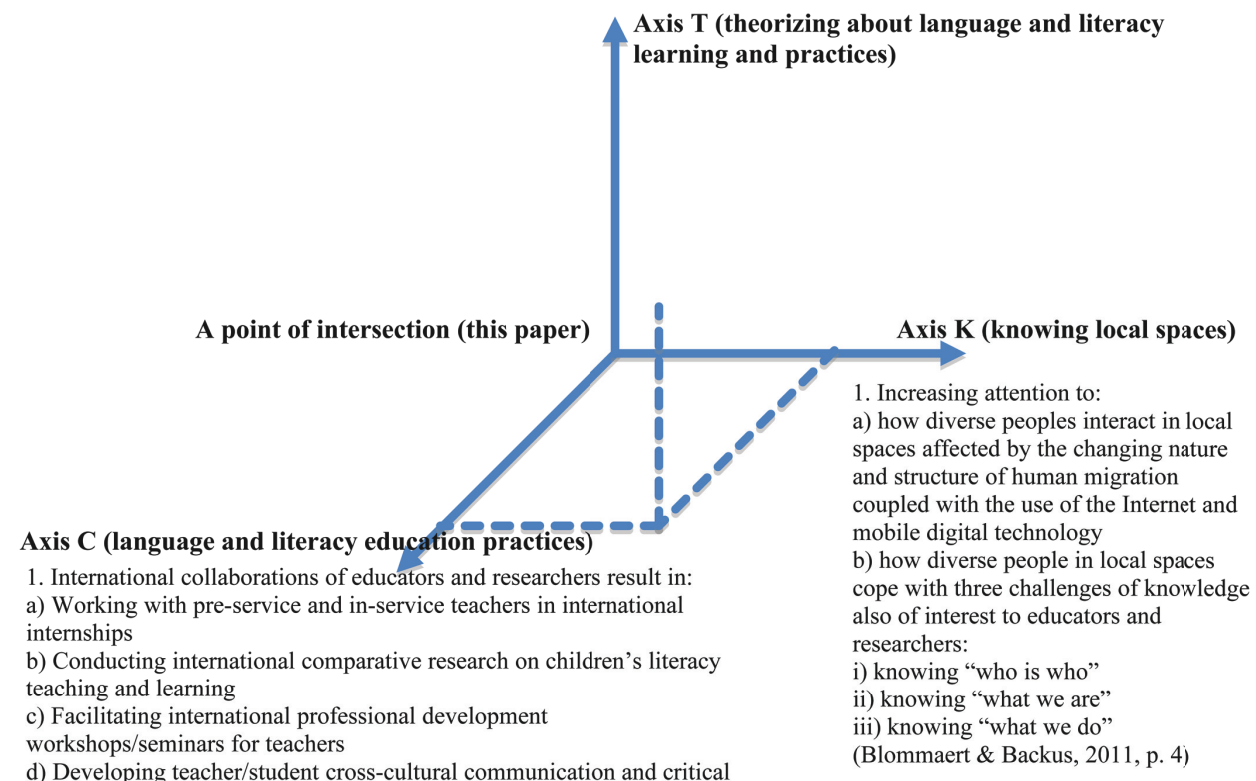

d) Developing teacher/student cross-cultural communication and critical thinking through international education projects

(Leung, Richards, Lassonde, 2014, p. 6)

Figure 1. Three Dimensions of Inquiries in Contemporary Literacy Research and Education

incorporating cultural resources to generate innovative and persuasive inquiries that can sustain international networks of researchers and educators interested in improving literacy education for students across international contexts and subject areas (e.g., Hall \& al., 2013; Leung \& al., 2014). The aim of this paper is to briefly discuss current research interests and teaching practices in language and literacy education that can provide insights into three challenges of knowledge faced by contemporary literacy 
researchers and educators: "knowing who is who, what we are and what it is we do" (Blommaert \& Backus, 2011, p. 4). I assume that these challenges are significant for language and literacy research and education because they focus upon contemporary social and cultural practices with language and literacy in everyday home, community, and school situations magnified by trends in contemporary human migration and human digital communication.

The following background section discusses each axis depicted in Figure One in more detail with particular attention to three significant global events during the past 25 years. Two sections discuss connections between the global events and language and literacy research and education in local communities. A concluding section provides a final reflection about key points.

\section{BACKGROUND}

This section describes the three dimensions of Figure One in more detail. Axis ' $R$ ' indicates three areas of investigation. The first area of inquiry focuses on children's language and literacy learning in relation to the ordinary home/local communities where children reside. Particular attention focuses upon the ways children's activities are mediated by language/communication through the use of tools (e.g., electronic devices, toys) in the contexts of family and peer social relationships and situations such as children's play. The second area concerns investigations of children's language and literacy learning in relation to school/classroom settings. In these spaces, researchers give attention to children's uses of hybrid modes of language for making meaning while reading/writing for more formal, educational purposes. A key idea is that children's language and literacy learning occurs in particular spaces in connection with pedagogical practices, teacher/student interactions and identities in use. The third area focuses upon studies of teacher education and professional development in the context of calls for reform of (teacher) education, societal demands upon school curriculum and literacy practices, recognition of learners' strengths and weaknesses and the particular concerns of teachers and students (Hall, Cremin, Comber \& Moll, 2013).

Axis ' $\mathrm{K}$ ' indicates a set of contemporary processes that are related and reinforce one another: a) dynamic human labor-related international migrations and b) continuing development of inter- 
net/mobile/communication digital technologies, which allows people to remain simultaneously connected with other people in multiple communities. These contemporary processes arise from two particular events occurring about 25 years ago. The first event occurred in December 1990 with the development of the first web browser, the first web server, and the first web site. These tools supported the development of the internet, which was further connected to improving mobile digital technology for communication including: telephones, television, print and online media. A result is that people may stay connected to their communities of origin "[constituting] daily routines, activities, and institutional affiliations that simultaneously connect them to more than one society" (Lam \& Warriner, 2012, p. 194).

The second event occurred on 8 December 1991 with the dissolution of the Soviet Union through the signing of the Belavezha Accords by the leaders of three Soviet Republics: Russia, Ukraine and Belarus. This document was further confirmed by the signing of the Alma-Ata Protocol on 21 December 1991, which created the Commonwealth of Independent States (CIS). As a result of the breakup of the Soviet empire, people from 15 newly independent Eastern European and Central Asian nations (Armenia, Azerbaijan, Belarus, Estonia, Georgia, Kazakhstan, Kyrgyzstan, Latvia, Lithuania, Moldova, Russia, Tajikistan, Turkmenistan, Ukraine, Uzbekistan) were added to cross-border labor migrations of people from China and India. Within a few years, the number of people globally available for employment doubled from 1.5 billion to about 3 billion (Freeman, 2008). Since that time, earlier ideas about migration and societal formation existing in the $20^{\text {th }}$ century, which focused on assimilation and border control, have been weakened or blurred (Castles, 2002).

Contemporary human mobility continues to transform societies and (re)form local communities. One result is the difficulty of understanding the concept of 'community' under dynamic conditions of human mobility, "There is a need to problematize bounded or unitary conceptions of 'home' or 'community'. Communities may be fluid or transitory or experienced in different ways by different children and literacies may move within and across different locations" (Pahl \& Burnett, 2013, p. 3).

A second result is that human social action, identity and language and literacy practices are linked to, and considered as produced by, people acting and reacting to one another across 
multiple geographical spaces (Mills \& Comber, 2013). Blommaert (2010) explained a recent shift in academic attention to spaces as contexts for social action (a spatial turn),

"[T]he main challenge for [academic] disciplines... consists in loosening the connections between culture and a particular territory. Whereas more traditional approaches appeared to tacitly assume that societies and their features belonged to one particular geographical area and thus attributed an absolute spatiality to culture, the emphasis on situatedness emphasizes flows, trajectories, movements and thus the relative spatiality of culture... [I]t is one of the main assumptions of globalization studies that multiple cultures can exist in one space and that conversely, one culture can be produced in different spaces" (p. 63).

Contemporary everyday community spaces such as school classrooms are viewed as simultaneously multilingual, multimaterial, multimodal, and multiperspectival. Spaces are being defined by "multiple narrators, simultaneity of different points of view, and multipresentness of time [places inside multiple 'stories' for people to be and to take part]" (Chambers, 1985, p. 63).

Taken together, dynamic conditions of human migrations, which push against the boundaries of national/territorial spaces, plus the rapid development of internet/mobile digital technology and increasing attention to what people do with language and literacies in homes, communities and school classrooms have raised basic questions for researchers about how people identify with other people within and across groups, how groups define themselves and how groups define their practices/activities. These questions can be stated as, "who is who, what we are and what it is we do" (Blommaert \& Backus, 2011, p. 4). These questions represent growing contemporary concerns about building knowledge about people in multiple localities and what lived, embodied and situated uses of language and literacies are taken up, with whom, for what purposes, with what consequences, in which spaces, among other concerns. Such basic challenges are briefly summarized in Figure One as three areas of knowledge building. Each of these challenges of understanding is briefly summarized in the following section. 


\section{GLOBAL CONTEXTS; LOCAL CHALLENGES}

The challenge of knowing "who is who" refers to remembering or recognizing familiar people as well as becoming acquainted with people who are unfamiliar, and learning to recognize them. Navigating everyday social, political, economic, religious relations within and across communities becomes increasingly significant for language and literacy learning (Castles, 2002; Moje, 2013). What people consider as familiar is locally proposed, locally recognized, and locally acknowledged and carries significant local and extra-local consequences (Bloome \& al. 2005). Gilmore and Wyman (2103), for example, discussed a series of ethnographic studies in Alaskan Native communities during the past thirty years. These studies showed indigenous peoples overcoming narratives of shame and deficits, documenting and recognizing indigenous knowledge to connect youth with their elders and community ways of knowing, and encouraging youth to serve as agents of change. Li (2013) showed the complexities of immigration and schooling through discussion of Asian English language learners' identities, literacy practices, and literacy pedagogies. Li proposed culturally-focused pedagogy to help students generate ethnographic data about socio-cultural contexts of learning in and out of school, "valuing students' first language and culture... as funds of knowledge" (p. 148) and developing strategies that help students and teachers construct alternative local spaces where different and/or contested cultural codes and social contexts could be reconciled and coexist. "Cultural reconciliation [and translation] involves helping students recognize the consequences of culturally different literacies... It involves continual interface and exchange of cultural difference" (p. 148, 149). Engaging in cultural translation was defined as grappling with basic questions about ' $\mathrm{I}$ ', 'we' and 'they' with regard to alternative languages and cultures. Reyes and Esteban-Guitart (2013) discussed American and European children's developing uses and combinations of written language-drawing from and recreating cultural and linguistic knowledge as well as developing alternative literacy practices in conditions of migration. The authors showed that these activities have also implications for redefining ideas about literacy - moving away from "the traditional view of 'literacy' as the development of linguistic strategies in regard to reading and writing" towards a 
redefinition of "the linguistic forms and meaning developed through interactions among individuals in several domains of activity, and in different places and situations" (p. 167).

Taken together, these examples suggest that attempts to respond to the question of knowing 'who is who' have been linked with the consideration of particular social and cultural contexts. "As researchers, we are required to ask, how can we know and understand the messy particularities and awkward histories of people as they interact with each other? How can we describe those interactions and the social relationships they build? What sense can we make of them? And to what end?" (Bloome, 2015, p. 180). Questions such as these reflect increasing attention to how people adapt to, cope with, and even contest unfamiliar peoples and their literacy practices. Although, "'the other' used to be relatively well known and rather predictable, 'the other' now has become entirely unpredictable because of dynamic migration and mobile technology, and little can be presupposed with respect to the cultural, linguistic, and other features of 'the Other' " (Blommaert \& Backus, 2011, p. 4).

Second, knowing "what we are" represents the contemporary challenge of understanding how groups define themselves. In particular, this challenge includes building understanding about how people define knowledge, human identities, cultural ideologies, and ways of understanding and describing the world around them as they interact with other people and groups and encounter other ways of using language (including reading and writing) for making meaning in particular local spaces (Bloome, 2015). Research by Stone-MacDonald (2014) can be connected with this challenge. This author described her ethnographic dissertation research at a school and local community in Tanzania, "The purpose of my larger dissertation study was to explore how local context and beliefs about disability influenced the ways participants understood their roles at the school and the ways they implemented curriculum" (p. 101). In particular, her study investigated how teachers taught school and cultural literacies to students with disabilities. Cultural literacy was defined as knowledge (e.g., knowing how to do household skills such as washing clothes or demonstrate social skills such as receiving guests and helping them to wash their hands) important and essential for everyday life for local community residents. School literacy was defined as the curriculum (e.g., knowing how to read, how to write, 
knowing historical events and people) designed by the school for preparing students with disabilities to participate in local community life. Conclusions from the study were summarized in two directions: a) didactic instructional practices with reading and writing were confined to the school classrooms and remained unconnected with the students' daily lives, and b) clear opportunities for learning exist that bring together local cultural literacies and school curriculum. Also significant was that knowledge of 'what we are' was clearly lacking in the professional development workshops led by consultants from the international partners of the school, "[who] were experts in their fields and had knowledge of materials and teacher education in their own Western contexts, but they were not familiar with the Tanzanian educational context, the current state of teacher education there, or the language [and culture]" (p. 119).

Raising the question of knowing 'what we are' indicates interest in how prior knowledge about local places and ways of life can serve as primary contexts for student learning even though current educational trends contest the value of everyday knowledge and cultural experiences as a basis for reading and writing in school.

"[C]urrent educational discourses seek to standardize the experience of students from diverse geographical and cultural places so that they may compete in the global economy. Such a goal essentially dismisses the idea of place as a primary experiential or educational context, displaces it with traditional disciplinary content and technological skills, and abandons places to the workings of the global market. Place-based educators do not dismiss the importance of content and skills, but argue that the study of places can help increase student engagement and understanding through multidisciplinary, experiential, and intergenerational learning that is not only relevant but potentially contributes to the well-being of community life" (Gruenewald, 2003, p. 7).

The third challenge of knowing 'what we do' connects the study of places with normative practices for teaching and learning. Standard practices may be held in tension with collaborative local practices and literacies across multiple sites, kinds of texts, artifacts, concepts about homes and communities, notions of time, and ways of using texts in social spaces. This challenge can be connected to research, for example, that investigates what children do with discourse and materials to build knowledge about, and shape, their social worlds (e.g., Vass, Littleton, Miell \& Jones, 2008). An object 
ethnographic study, conducted by Carrington and Dowdall (2013), investigated the LEGO play of two young boys. This inquiry explored the design of LEGO artifacts, their social biography, and the use of the objects as "players in the building and maintenance of social and cultural myth... Undertaking the object ethnography positions LEGO as a material artifact, an agent in the construction of everyday social worlds, and a contributor to the larger cultural and political narratives that shape the world in which we live" (p. 97). As a result of an object-oriented ethnography, the authors gave attention to what the boys did with LEGOs and how these objects helped the boys create beliefs and normative literacy practices. In particular, the investigation focused upon, "the LEGO activities of two boys... [building] identities and early repertoires of practice in relation to valued artifacts and within the material culture of their everyday lives... [how their] early literacy practices and identities are crosscut by the power and reach of global and local media forms" (p. 96). The authors constructed an ethnographic/historical perspective of a set of LEGO objects as part of everyday life and the ways the boys used the objects to shape their social worlds. The investigation also showed how the boys participated in media-related discourses around creative assembly that crossed national borders supported by a "global media enterprise" (p. 105). The LEGO brand included toys, theme parks, video games, magazines, and a website. "The LEGO group is now the world's fourth largest manufacturer of toys, with LEGO products being sold in more than 130 countries stretching from Europe through Asia to Australia" (p. 102). Importantly, the authors explained how the boys' play with LEGOs as a global media form represented a means of developing creative combinations of ideas with objects to create new understandings that have the potential to contribute to world-wide knowledge-based disciplinary communities in the sciences, business, and the arts.

In addition, the challenge of knowing 'what we do' can be exemplified through what people do in school spaces. Edwards, Condy and Malik (2014) described Zones D'Education Priorities (Project ZEP) located in Mauritius. The overall goal of the project was "to improve educational opportunities through improving the educational capacity of teacher educators, head teachers, teachers, and parents in order to better support the learning of all children" (p. 250). More specific goals of the project included preparation of inservice providers and action researchers, training in innovative 
pedagogical practices, and promoting teacher reflection to create lessons that would encourage active student participation. In this project, the developers adopted a "community asset building model" rather than a "needs assessment model" in order to understand the local intellectual, social, and cultural resources, which were available for teaching and learning. The "community asset building model" intentionally valued the role of the stranger-the outside provider of education services-to ask questions and raise perspectives about uses of community resources that local educators may not ask because the situations and resources seem so familiar to them. Local providers of inservice education identified topics such as innovative teaching of phonics, reading fluency, and classroom management for emphasis. The local providers used feedback to coach teachers in improving classroom reading activities, word identification, vocabulary instruction, and comprehension activities for smaller groups of students. The outside providers considered how those topics could be discussed using cooperative learning to promote critical thinking about the topics. In this situation, the local professional development providers focused on familiar topics for teachers-while the outside provider considered how to ask questions and raise perspectives about the local practices to support further understanding about 'knowing what we do'.

Taken together, these two brief examples of literacy research and teacher collaboration indicate that inquiries for building knowledge about 'what we do' have focused upon children's activities with objects to create beliefs and normative literacy practice in local home or community spaces as well as teachers' pedagogical practices and professional development activities at local school sites. Building understanding about the general question about how people define 'what we do' has also been linked with building knowledge about how children and teachers envision themselves as enacting particular normative literacy and teaching practices.

Axis ' $C$ ' shows four main directions of international collaboration among researchers and educators given the developments along axis $\mathrm{K}$ and along axis $\mathrm{R}$. Briefly, the international collaborations have concentrated upon the development of international internships, which bring together in-service and pre-service teachers, the formation of international research projects that involve comparisons of literacy teaching and learning involving children in multiple locations, the development of international professional development workshops/seminars and the development of 
projects that support cross-cultural communication and critical thinking for educational purposes (Leung, Richards, Lassonde, 2014).

In sum, Figure One portrays a possible way of bringing together theorizing about language and literacy learning and practices, knowledge about local spaces and significant education practices connected with language and literacy educators. Taken together, these three directions can generate interesting combinations of theory, local knowledge and practice for literacy researchers and educators interested in children's language and literacy.

\section{GLOBAL CONTEXTS; LOCAL OPPORTUNITIES}

In addition to a series of challenges, contemporary global conditions of dynamic human migration connected with mobile digital communications technology and the widespread geographic reach of the internet have made particular opportunities available to language and literacy researchers and educators. Sheehy (2013), for example, argued for the significance of "a geographic explanation of context-the social, relational processes, imaginings and artifacts that distinguish one classroom and one school from another" (p. 400) in order to understand how particular places provide opportunities for use of resources by people at those places. This particular discussion included four key research goals that are important to understanding geographic contexts for literacy practices: a) analyzing how networks of communication span multiple locations, b) identifying events transpiring at each location, c) making visible contested practices with literacy in each location, and d) showing how contested practices are established, maintained, and changed through the creation of boundaries or borders erected, reestablished and even (re)signified through human interaction and migration.

A second example of an opportunity to research and learn about contemporary language and literacy learning is developed by Rosemberg, Stein, and Alam (2013), who explored what counts as local knowledge connected with literacy education. These authors discussed social spaces in homes as sites for implementing three pedagogical practices to support children's literacy learning in impoverished and marginal communities in Argentina. The practices were planned so that children could use writing to draw upon 
their local ways of knowing and their home/community interpersonal interactions and languages to produce knowledge about their living spaces and generate new knowledge. The first practice concerned the production of ethnographically informed reading books. The events and plots of the ethnographic children's books showed people and objects from the perspectives of children residing in local communities and the books were written in standard and community dialects. As a result, "knowledge of the local physical, social and spiritual world is juxtaposed with scientific knowledge and school curriculum" (p. 73). Thus, school and home perspectives were brought together by teachers and students to coexist in local community spaces. A second pedagogical practice introduced the ethnographic reading books to participants in a family early literacy program in which researchers visited the home spaces of low income urban families (including migrating families) to observe and record reading and writing situations involving multiple family participants and how they enter into literacy-related activities. "In [these collaboration networks] the children's siblings, cousins, and mothers assume different roles, which are not interchangeable. In this way, they show the importance of social networks for children's development" (p. 76). The ethnographic reading books were used within existing social networks. Third, a tutoring program was designed and implemented through children's social networks. Older children were prepared to help younger children read stories, reflect upon questions and terms, and use games to raise interest and awareness of written texts in connection with previous life experiences. Through these pedagogical practices, children were introduced to reading and writing as multi-perspectival social events with specific activities that could bridge multiple sites by drawing upon existing social networks. In sum, the authors explained that the use of ethnographic reading books served to generate literacy activities that bridged home and school spaces because the book characters and plot incidents were composed based on observations of students' daily lives in events occurring in homes and wider communities.

"Each event is local, particular, and filled with the complexities and contradictions of human relationships. It makes a difference who the people are, who they are with, where they came from, and what they are doing and where they are doing it.... And each of these events, while geographically specific and embodied, is simultaneously a 
nexus of diverse geographic locations, histories, and cultures.... There is no answer to how the local should be theorized, and there is no final theory of the local. There is only the process, and necessarily it is local, particular, and constantly evolving. To engage... in such processes and theorizing is to transform what counts as knowledge and as importantly, who counts and how they count (Bloome, 2014, p. $179,181)$.

\section{CLOSING REFLECTION}

This paper has presented three challenges to building knowledge about children's and young peoples' language and literacy learning posed by contemporary conditions of dynamic human migration connected with developing mobile digital communications and the widespread use of the internet. The first challenge of knowing 'who is who' has raised questions about familiarity. In particular, researchers and educators have been confronted with challenging questions about how to understand the people with whom they interact. The second challenge of knowing "what we are" raised questions about what knowledge is used by people to define their social relations, social identities, social structures and ideologies in order to establish, sustain, or contest particular social meanings. The third challenge of knowing "what we do" raised questions about how people define normative practices with available intellectual, social, and material resources including language and literacy practices. These challenges of knowledge have been composed as self-reflective questions about human relations, identities, knowledge and ways of knowing, and normative literacy and pedagogical practices. Focusing attention upon such questions is one way of building understanding about extant social relations, identities, language and literacy practices, and modes of communication created by people interacting with one another in particular spaces.

Further discussion presented two brief examples of opportunities to learn from international research and collaboration related to language and literacy education for children and youth at home and at school in various communities around the world. The examples can provide research and instructional ideas for researchers and educators seeking to understand how people define significant language and literacy practices within and across local communi- 
ties. Finally, the examples can serve as resources for imagining future lines of teaching and research related to language and literacy education for children and youth in local communities around the world.

REFERENCES Blommaert, J. (2010). The Sociolinguistics of globalization. Cambridge, UK: Cambridge University Press.

Blommaert, J. \& Backus, A. (2011). Repertoires revisited: 'knowing language' in superdiversity. Working Papers in Urban Language and Literacies 67, accessed 2 May 2016 at www.kcl.ac.uk/ldc.

Bloome, D., Carter, S., Christian, B., Otto, S., \& Shuart-Faris, N. (2005). Discourse analysis and the study of classroom language and literacy events A Microethnographic approach. Mahwah, NJ: Erlbaum.

Bloome, D. (2015). Almaty and Columbus: Theorizing the local. In: D. Landis \& S. Mirseitova (Eds.) Knowing what's local: Ethnographic inquiry, education and democracy (pp. 173-182). Charlotte, NC: Information Age Press.

Carrington, V. \& Dowdall, C. (2013). 'This is a job for Hazmat Guy!': Global media cultures and children's everyday lives, in: K. Hall, T. Cremin, B. Comber \& L. C. Moll (Eds), International Handbook of Research on Children's Literacy, Learning and Culture (pp. 96-107). Hoboken, NJ: John Wiley \& Sons, Ltd.

Castles, S. (2002). Migration and Community Formation under Conditions of Globalization. International Migration Review, 36, 4, Host Societies and the Reception of Immigrants: Institutions, Markets and Policies: 1143-1168.

Chambers, A. (1985). Booktalk: Occasional writing on literature and children. New York: Harper \& Row.

Edwards, W. L., Condy, J. \& Malik, S. (2014). Improving elementary school literacy in Mauritius through Project ZEP. In: C. B. Leung, J. C. Richards \& C. A. Lassonde (Eds.), International Collaborations in Literacy Research and Practice (pp. 249-272). Charlotte, NC: Information Age Publishing.

Freeman, R. (2008). The New global labor market. Focus, 26, 1, 1-6.

Gilmore, P. \& Wyman, L. (2103). An Ethnographic long look: Language and literacy over time and space in Alaska native communities. In: K. Hall, T. Cremin, B. Comber \& L. C. Moll (Eds.), International Handbook of Research on Children's Literacy, Learning and Culture (pp. 121-138). Hoboken, NJ: John Wiley \& Sons, Ltd.

Gruenewald, D. A. (2003). The Best of Both Worlds: A Critical Pedagogy of Place. Educational Researcher 32, 4, 3-12. 
Hall, K., Cremin, T., Comber, B. \& Moll, L. C. (Eds.), (2013). International Handbook of Research on Children's Literacy, Learning and Culture. Hoboken, NJ: John Wiley \& Sons, Ltd.

Lam, W. S. E. \& Warriner, D. S. (2012). Transnationalism and Literacy: Investigating the Mobility of People, Languages, Texts, and Practices in Contexts of Migration. Reading Research Quarterly, 47(2), 191-215.

Leung, C. B., Richards, J. C. \& Lassonde, C. A. (Eds.), (2014). International Collaborations in Literacy Research and Practice. Charlotte, NC: Information Age Publishing.

Li, G. (2013). Understanding English language learners' literacy from a cultural lens: An Asian perspective. In: K. Hall, T. Cremin, B. Comber \& L. C. Moll (Eds), International Handbook of Research on Children's Literacy, Learning and Culture (pp. 139-154). Hoboken, NJ: John Wiley \& Sons, Ltd.

Mills, K. A. \& Comber, B. (2013). Space, place and power: The Spatial turn in literacy research. In: K. Hall, T. Cremin, B. Comber \& L. C. Moll (Eds.), International Handbook of Research on Children's Literacy, Learning and Culture (pp. 412423). Hoboken, NJ: John Wiley \& Sons, Ltd.

Moje, E. B. (2013). Hybrid literacies in a post-hybrid world: Making a case for navigating. In: K. Hall, T. Cremin, B. Comber \& L. C. Moll (Eds.), International Handbook of Research on Children's Literacy, Learning and Culture (pp. 359-372). Hoboken, NJ: John Wiley \& Sons, Ltd.

Pahl, K. \& Burnett, C. (2013). Literacies in homes and communities. In: K. Hall, T. Cremin, B. Comber \& L. C. Moll (Eds.), International Handbook of Research on Children's Literacy, Learning and Culture (pp. 3-14). Hoboken, NJ: John Wiley \& Sons, Ltd.

Reyes, I. \& Esteban-Guitart, M. (2013). Exploring multiple literacies from homes and communities. In: K. Hall, T. Cremin, B. Comber \& L. C. Moll (Eds.), International Handbook of Research on Children's Literacy, Learning and Culture (pp. 155-171). Hoboken, NJ: John Wiley \& Sons, Ltd.

Rosemberg, C. R., Stein, A. \& Alam, F. (2013). At home and at school: Bridging literacy for children from poor rural or marginalized urban communities. In: K. Hall, T. Cremin, B. Comber \& L. C. Moll (Eds.), International Handbook of Research on Children's Literacy, Learning and Culture (pp. 67-82). Hoboken, NJ: John Wiley \& Sons, Ltd.

Stone-MacDonald, A. (2014). Getting past didactic instruction: Understanding the literacy curriculum for students with developmental disabilities. In: C. B. Leung, J. C. Richards \& C. A. Lassonde (Eds.), International Collaborations in Literacy Research and Practice (pp. 101-123). Charlotte, NC: Information Age Publishing. 
Vass, E., Littleton, K., Miell, D. \& Jones, A. (2008). The discourse of collaborative creative writing: Peer collaboration as a context for mutual inspiration. Thinking Skills and Creativity, 3(3), 192-202.

ДЕЈВИД ЛЕНДИС

МЕЪУНАРОДНИ КОНСУЛТАНТ

САД

РЕЗИМЕ

ЛОКАЛНИ ИЗАЗОВИ И МОГУЋНОСТИ ЗА ИСТРАЖИВАЧЕ И НАСТАВНИКЕ ЈЕЗИКА И ПИСМЕНОСТИ

Овај рад представља тродимензионални приказ савремених изазова и могућности за истраживаче и наставнике језика и писмености. Изазови и могућности су резултат динамичне миграције становништва, распрострањене употребе дигиталне мобилне технологије и развоја интернета. Коришћене су новије публикације које објашњавају изазове и могућности. Посебна пажња је посвећена простору као локалном контексту за учење језика и писмености. Дискусије о изазовима и могућностима доприносе разумевању тога како људи користе начине комуникације за развој, употребу и учење језика и савладавање писмености.

КљУчНЕ РЕчи: језик, писменост, истраживање, образовање, локални простори.

Овај чланак је објављен и дистрибуира се под лиценцом Creative Commons Ауторство-Некомерцијално Међународна 4.0 (CC BY-NC 4.0 |

https://creativecommons.org/licenses/by-nc/4.0/).

This paper is published and distributed under the terms and conditions of the Creative Commons Attribution-NonCommercial International 4.0 licence (CC BY-NC 4.0 | https://creativecommons.org/licenses/by-nc/4.0/). 